Council decision that Iraq had failed to comply; nor did they do so before commencing military operations. The language of Resolution 1441 tracked the language of Resolution 678 , and the resolution operated in the same way to authorize coalition forces to bring Iraq into compliance with its obligations. ${ }^{23}$

What does all this tell us about Iraq and the preemptive use of force? Was Operation Iraqi Freedom an example of preemptive use of force? Viewed as the final episode in a conflict initiated more than a dozen years earlier by Iraq's invasion of Kuwait, it may not seem so. However, in the context of the Security Council's resolutions, preemption of Iraq's possession and use of weapons of mass destruction was a principal objective of the coalition forces. A central consideration, at least from the U.S. point of view, was the risk embodied in allowing the Iraqi regime to defy the international community by pursuing weapons of mass destruction. But do U.S. actions show a disregard for international law? The answer here is clearly no. Both the United States and the international community had a firm basis for using preemptive force in the face of the past actions by Iraq and the threat that it posed, as seen over a protracted period of time. Preemptive use of force is certainly lawful where, as here, it represents an episode in an ongoing broader conflict initiated-without question-by the opponent and where, as here, it is consistent with the resolutions of the Security Council.

WILLIAM H. TAFT IVAND TODD F. BUCHWALD*

\title{
INTERNATIONAL LAW AND THE WAR IN IRAQ
}

In his speech before the United Nations (UN) in September 2002, President George W. Bush characterized the possible use of force against Iraq as necessary to enforce existing Security Council resolutions and to eliminate a dangerous threat to international peace and security. ${ }^{1}$ The Security Council responded by adopting Resolution 1441, which found Iraq to be in material breach of previous Security Council resolutions and threatened serious consequences for further intransigence. ${ }^{2}$ When Iraq refused to fully comply with these resolutions, the United States led an ad hoc "coalition of the willing" that invaded Iraq on March 19, 2003, quickly defeated Iraq's armed forces, and ended the regime of Saddam Hussein and the Ba'ath party. On May 1, 2003, President Bush announced that major combat operations in Iraq had ended. At the time of this writing, the United States has assumed the position of an occupying power that is responsible for rebuilding Iraq, as recognized by the Security Council in Resolution 1483.

Despite these actions, other leading nations (primarily France, Germany, and Russia) and many international scholars have argued that international law did not justify the war in Iraq. The first part of this paper will explain why their view failed to properly read existing Security Council resolutions to authorize the use of force. Even putting the United Nations to one side, the war was further justified as an exercise of self-defense. Under basic notions of customary international law, properly understood, the United States could have attacked Iraq

\footnotetext{
${ }^{23}$ For its part, the United States made clear that it would have preferred the Council to adopt a second resolution. Its view wias that such a resolution would have operated as an important demonstration of resolve by the international cornmunity to increase the pressure on Iraq and, ultimately, to reduce the likelihood that resort to force would be necessary. While the Council's inability to come together for such a resolution may have misled Iraq into believing it could wait out the process in New York, the absence of Council action in no way diminished the effect of what the Council had previously authorized.

* Mr. Taft is the Legal Adviser of the United States Department of State; Mr. Buchwald is the Assistant Legal Adviser for Political-Military Affairs of the United States Department of State.

${ }^{1}$ George W. Bush, UN General Assembly in New York City Address (Sept. 12, 2002), 38 WEEKLY COMP. PRES. DOC. 1529 (Sept. 16, 2002), available at <http://www.whitehouse.gov/news/releases/2002/09/20020912-1.html> [hereinafter Bush UN Address].

${ }^{2}$ SC Res. 1441 (Nov. 8, 2002).
} 
even without Security Council authorization. The second part of this paper will discuss why the toppling of Saddam Hussein's regime was justified as an exercise of anticipatory selfdefense.

This paper is divided into three sections. Part I lays out the background to the conflict with Iraq. Part II discusses the UN Security Council's authorization for the use of military force against Iraq. Part III explains why the United States could use force in anticipatory selfdefense. I conclude by sketching out the implications of these arguments for a future threatened by weapons of mass destruction (WMD), rogue nations, and terrorism.

\section{BACKGROUND}

Examination of the factual and legal setting leading up to the Iraq war will show that sufficient legal authority existed for the 2003 conflict with Iraq. On August 2, 1990, Iraq invaded Kuwait. The next day, the Security Council adopted Resolution 660, the first of many resolutions to condemn Iraq's actions and demand withdrawal from Kuwait. ${ }^{3}$ After diplomacy failed, the Security Council adopted Resolution 678, which gave Iraq until January 15, 1991, to implement Resolution 660 fully. ${ }^{4}$ Paragraph 2 of Resolution 678 authorizes member states "to use all necessary means to uphold and implement resolution 660 (1990) and all subsequent relevant resolutions and to restore international peace and security in the area." Iraq refused to withdraw from Kuwait before the January 15th deadline, and Operation Desert Storm began the next day. Iraq was expelled from Kuwait on February 27, 1991.

On April 3, 1991, the Security Council adopted Resolution 687, which established the conditions for a formal cease-fire suspending hostilities in the Persian Gulf. Resolution 687 required Iraq to: (1) destroy its chemical and biological weapons and ballistic missiles and agree to onsite inspections; (2) not use, develop, construct, or acquire such WMD and their delivery systems; (3) not acquire or develop nuclear weapons or nuclear-weapons-usable material or components; and (4) accept on-site inspection and destroy nuclear-related weapons or materials. ${ }^{6}$ To carry out the inspections, the resolution established a United Nations Special Commission (UNSCOM) to cooperate with the International Atomic Energy Agency (IAEA), which was to take custody of all of Iraq's nuclear-weapons materials. On April 6, 1991, Iraq officially accepted the terms, and a formal cease-fire went into effect between Iraq, Kuwait, and the nations that had cooperated with Kuwait, including the United States. ${ }^{7}$

\footnotetext{
${ }^{3}$ See SC Res. 660 (Aug. 2, 1990). See also SC Res. 661 (Aug. 6, 1990) (establishing oil embargo and sanctions regime against Iraq and Kuwait); SC Res. 662 (Aug. 9, 1990) (deciding that Iraq's annexation of Kuwait has no legal validity); SC Res. 664 (Aug., 18, 1990) (demanding that Iraq permit and facilitate the immediate departure from Kuwait of third-party nationals); SC Res. 665 (Aug. 25, 1990) (calling upon allied nations to use necessary measures to enforce embargo established in SC Res.661); SC Res. 666 (Sept. 13, 1990) (implementing sanctions regime and the humanitarian needs exception); SC Res. 667 (Sept. 16, 1990) (demanding that Iraq immediately protect safety of diplomatic and consular personnel and premises in Kuwait); SC Res. 669 (Sept. 24, 1990) (relating to Jordan's request for relief from effects of implementing oil embargo and sanctions regime); SC Res. 670 (Sept. 25, 1990) (regulating aircraft transporting cargo to Iraq or Kuwait and reaffirming Iraq's liability for grave breaches of the Geneva Convention Relative to the Protection of Civilian Persons in Time of War); SC Res. 674 (Oct. 29, 1990) (condemning Iraqi mistreatment of Kuwaiti and third-party nationals and inviting collection of materials to bring charges against Iraq for its violations of international law); SC Res. 677 (Nov. 28, 1990) (condemning Iraqi attempts to destroy demographic composition of Kuwait and Kuwaiti civil records).

${ }^{4}$ SC Res. 678 (Nov. 29, 1990).

${ }^{5}$ Id.

${ }^{6}$ SC Res. 687 (Apr. 3, 1991).

${ }^{7}$ Toward the end of the Gulf war, Iraq brutally suppressed Kurdish insurrections in Iraqi Kurdistan, causing the flight of hundreds of thousands of civilians to Iran and Turkey. In response, the Security Council adopted SC Res. 688 (Apr. 5, 1991), which condemned "the repression of the Iraqi civilian population" and found that the consequences of such repression caused "a massive flow of refugees towards and across international frontiers and ... crossborder incursions" that threatened international peace and security in the region. To aid the refugees who had fled northern Iraq, the coalition established a no-fly zone prohibiting Iraqi military aircraft from flying north of the 36th parallel. Due to further repression of the civilian population in 1992, British, French and U.S. coalition forces established an additional no-fly zone south of the 32 nd parallel.
} 
From the beginning, Iraq resisted UNSCOM's efforts to perform its mandate. On August 15, 1991 , little more than four months after the adoption of Resolution 687, the Security Council "condemn[ed]" Iraq's "serious violation" of a number of its obligations regarding the destruction and dismantling of its WMD program and of its agreement to cooperate with UNSCOM and the IAEA and stated that the violation "constitutes a material breach of the relevant provisions of [Resolution 687] which established a cease-fire and provided the conditions essential to the restoration of peace and security in the region." ${ }^{8}$ Iraq's intransigence continued for years. In June of 1996, the Security Council "deplored" the refusal of Iraq to allow access to UNSCOM inspectors and Iraq's "clear violations" of its resolutions. ${ }^{9}$ In June 1997, the Council again "condemn[ed] repeated refusal of Iraqi authorities to provide access" to UNSCOM inspectors as a "clear and flagrant" violation of its resolutions and demanded full, immediate, and unconditional compliance. ${ }^{10}$ In the fall of 1997 , Resolution 1137 "condemn[ed] ... the continued violations by Iraq of its obligations under the relevant resolutions to cooperate fully and unconditionally with [UNSCOM]," found that the situation continued to constitute a threat to international peace and security, and warned that "serious consequences" would result if Iraq failed to comply with its international obligations."

In February 1998, UN Secretary-General Kofi Annan secured a memorandum of understanding confirming Iraq's acceptance of all relevant Security Council resolutions and its reaffirmation to cooperate fully with UNSCOM and the IAEA. Nonetheless, Iraq formally halted all cooperation with UNSCOM at the end of October. The Security Council responded by condemning Iraq's decision as a "flagrant violation of resolution $687 \ldots$ and other relevant resolutions." 12 On December 15, UNSCOM reported that it could not complete its mandate due to Iraq's obstructionism. The next day, the United States and Britain launched a seventyhour missile and aircraft bombing campaign against approximately one hundred targets in Iraq. For the next four years, Iraq refused to permit UN inspections. In December 1999, the Security Courncil decided to disband UNSCOM and replace it with the United Nations Monitoring, Verification and Inspection Commission (UNMOVIC). ${ }^{13}$

The terrorist attacks on September 11, 2001, and the United States' military response in Afghanistan against the Qaeda terrorist organization and the Taliban militia that harbored it, led to a sharper focus on the Iraq problem. ${ }^{14}$ The attacks on the World Trade Center and the Pentagon, carried out by Al Qaeda operatives trained and led from their bases in Afghanistan, demonstrated the threat posed by terrorists who could seek safe haven in rogue nations with potential access to WMD. As President Bush said in his January 2002 State of the Union address:

States like these, and their terrorist allies, constitute an axis of evil, arming to threaten the peace: of the world. By seeking weapons of mass destruction, these regimes pose a grave and growing danger. They could provide these arms to terrorists, giving them the means to match their hatred. They could attack our allies or attempt to blackmail the United States. In any of these cases, the price of indifference would be catastrophic. ${ }^{15}$

\footnotetext{
${ }^{8}$ SC Res. 707 (Aug. 15, 1991).

${ }^{9}$ SC Res. 1060 (June 12, 1996).

${ }^{10}$ SC Res. 1115 (June 21, 1997).

${ }^{11}$ SC Res. 1137 (Nov. 12, 1997).

${ }^{12}$ SC Res. 1205 (Nov. 5, 1998).

13 SC Res. 1284 (Dec. 17, 1999).

${ }^{14}$ I have discussed the domestic legal authority for the war in Afghanistan elsewhere. See Robert J. Delahunty \& John C. Yoo, The President's Constitutional Authority to Conduct Military Operations Against Terrorist Organizations and the Nations that Harbor or Support Them, 25 HARV. J.L. \& PUB. POL'Y 487 (2002).

${ }^{15}$ George W. Bush, State of the Union Address (Jan. 29, 2002), 38 WEEkLY COMP. Pres. DoC. 125, 135 (Feb. 4, 2002), available at $<$ http://www.whitehouse.gov/news/releases/2002/01/iraq/20020129-11.html>.
} 
On September 12, 2002, President Bush challenged the United Nations to address the threat posed by Iraq as highlighted by its continuing defiance of the Security Council. ${ }^{16} \mathrm{On}$ November 8, the Security Council unanimously approved Resolution 1441 to address "the threat Iraq's non-compliance with Council resolutions and proliferation of weapons of mass destruction and long-range missiles poses to international peace and security." ${ }^{17}$ The resolution "deplor[es]" the absence of international inspections in Iraq since December 1998 and Iraq's continued failure to renounce international terrorism and cease the repression of its civilian population, and gives Iraq "a final opportunity to comply with its disarmament obligations under relevant resolutions of the Council." ${ }^{18}$ It reminded Iraq that the Security Council has repeatedly warned that "serious consequences" would result from the continued violation of its obligations. ${ }^{19}$

Although Iraq responded to the resolution by permitting the resumption of inspections, it never took advantage of its final opportunity to comply with its international obligations. Iraq submitted a declaration on December 7,2002 , but the declaration was incomplete, inaccurate, and composed mostly of recycled information. Iraq's declaration clearly failed to address any of the outstanding disarmament questions that previous disarmament inspectors had publicly documented. The reports submitted by UNMOVIC to the Council confirmed these shortcomings. ${ }^{20}$ Iraq's submission of a declaration that did not comply with Resolution 1441 was a further material breach of its obligations. As President Bush stated on March 6, 2003, Iraq continued to produce missiles that violate the restrictions in Resolution 687 and to hide biological and chemical agents to avoid detection by international inspectors. ${ }^{21}$ No permanent member of the UN Security Council claimed that Iraq had lived up to its obligations in Resolution 1441. On February 5, 2003, Secretary of State Colin Powell delivered a comprehensive presentation to the Security Council demonstrating Iraq's ongoing WMD efforts and their concealment from UN inspectors. ${ }^{22}$ As Dr. Blix indicated to the Security Council on January 27, 2003, Iraq had not come "to a genuine acceptance, not even today, of the disarmament which was demanded of it." 23

The conclusion is inescapable that at the time of the outbreak of the 2003 conflict, Iraq had decided to refuse to comply with its disarmament obligations. This placed Iraq in material breach of Resolution 1441 as well as Resolution 687. At the time of this writing, coalition forces in Iraq continue to search for WMD sites; while no weapons have yet been discovered,

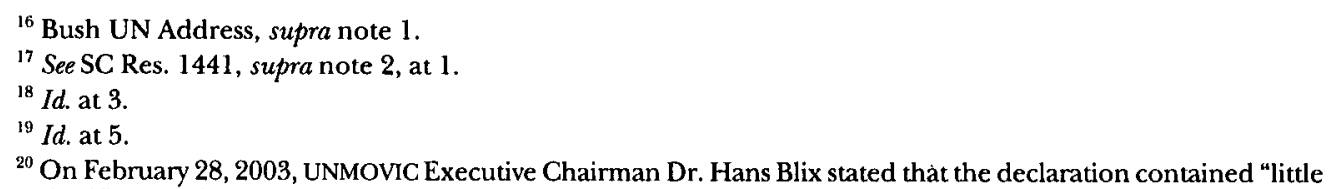
new significant information ... relating to proscribed weapons systems." Annex of the Twelfth Quarterly Report of the Executive Chairman of the United Nations Monitoring, Verification and Inspection Commission in Accordance with Paragraph 12 of Security Council Resolution 1284, para. 7, available at<http://www.un.org/depts/unmovic/ documents / 2003-232.pdf $>$. On January 27, 2003, Dr. Blix stated that the Iraqi declaration did not contain "any new evidence that would eliminate" the "many open disarmament issues." Update on Inspection to the UN Security Council (Jan. 27, 2003), at 3. On March 7, 2003, Dr. Blix repeated his conclusion that, "It was a disappointment that Iraq's declaration of 7 December did not bring new documentary evidence." Oral Introduction of the Twelfth Quarterly Report of UNMOVIC, at 2.

${ }^{21}$ Iraq failed to provide access to all officials for interview by inspectors; intimidated witnesses with threats; undertook massive efforts to deceive and defeat inspectors, including cleanup and transshipment activities at nearly thirty sites; failed to provide numerous documents requested by UNMOVIC; failed to list any WMD personnel beyond a period ending in 1991 or to include many of those identified previously by UNSCOM; and failed to account for seventeen empty chemical warheads subsequently discovered by weapons inspectors, as well as over 2000 pages of Iraqi documents regarding past uranium enrichment programs. The Bush administration's more detailed description of Iraq's refusal to comply with relevant Security Council resolutions can be found in 149 CONG. REC. H1957-60 (daily ed. Mar. 19, 2003) (Report in Connection with Presidential Determination Under Public Law 107-243).

${ }^{22}$ U.S. Secretary of State Colin Powell Addresses U.N. Security Council (Feb. 5, 2003), available at<http://www.whitehouse. gov/news/releases/2003/02/20030205-1.htm>.

${ }^{29}$ The Security Council: 27 January 2003: an Update on Inspection (as delivered) by Executive Chairman of UNMOVIC Dr. Hans Blix, available at <http://www.unmovic.org>. 
it may take months if not years to learn the fate of Iraq's WMD stockpile. It has become clearer since the war that Saddam Hussein had allowed Al Qaeda-linked terrorists to operate from Iraq. Nonetheless, these ex post developments do not directly bear on the justification for the use of force ex ante. What is important for jus ad bellum purposes is what the United States and its allies reasonably understood the facts to be at the start of hostilities, not what turned up afterwards.

\section{UN SECURITY COUNCIL AUTHORIZATION FOR THE USE OF FORCE AGAINST IRAQ}

In light of this background, two independent sources of law provided the United States and its allies with authority to use force in Iraq: UN Security Council resolutions and the right to self-defense. Resolution 678 authorized member states "to use all necessary means to uphold and implement resolution 660 (1990) and all subsequent relevant resolutions and to restore international peace and security in the area." ${ }^{24}$ One of the most significant "subsequent relevant resolutions" was Resolution 687. Pursuant to Resolution 678, the United States could use force not only to enforce Resolution 687's cease-fire, but also to restore "international peace and security" to the region. In Resolution 1441, the Security Council unanimously found that Iraq was in material breach of these earlier resolutions and that its continuing development of WMD programs, its support for terrorism, and its repression of the civilian population presented an ongoing threat to international peace and security.

These findings triggered Resolution 678's authorization to use force in Iraq. Suspending the cease-fire and resuming hostilities with Iraq was an appropriate response to Iraq's material breaches of Resolution 687 . Over the years, Iraq repeatedly refused to respond to diplomatic overtures and other nonmilitary attempts to force compliance with its obligations to disarm and to permit full UN inspections of its WMD program. Military force was necessary to obtain Iraqi compliance with the terms of the cease-fire and to restore international peace and security to the region.

Some have argued, however, that, Resolution 678's authorization had expired. Representatives from France, Germany, and Russia, for example, seemed to take the position that because the current members of the Security Council would not agree to the use of force in the spring of 2003, the 1991 resolution's broad authorization was somehow extinguished. That view is simply wrong as a matter of UN practice and as a matter of law. The UN Security Council has not readily authorized the use of force in the past (indeed, it appears to have done so only in the context of seven conflicts), nor has it rescinded those decisions lightly. When the Security Council has taken the serious step of ending its authorization to use force, it has only done so in one of two ways: either by expressly terminating the prior authorization or by setting an up-front time limit on the authorization. ${ }^{25}$ With regard to Bosnia, for example, the Security Council ended the legal authority for the use of force by expressly terminating the previous authorization in a separate resolution, while in Somalia, the Security Council explicitly established a sunset date when it extended the authorization. ${ }^{26}$ In fact, when the Security Council has wanted to reserve for itself whether the conditions for termination of its authorization have been met rather than leave the matter to the member states, it has explicitly done so. ${ }^{27}$

${ }^{24}$ See SC Res. 678, supra note 4, para. 2.

${ }^{25}$ See, e.g., SC Res. 1031 (Dec. 15, 1995), at 3 (Bosnia) (deciding that "the authority to take certain measures conferred upon States by [various UN Security Council resolutions] shall be terminated"); SC Res. 954 (Nov. 4, 1994), at 3 (extending the mandate for the U.N. Mission in Somalia (UNOSOM II) for a "final period" until March 31, 1995); SC Res. 929 (June 22, 1994), at 2 (Rwanda) (specifying that "the mission of Member States cooperating with the Secretary-General will be limited to a period of two months following the adoption of the present resolution," if not earlier).

${ }^{26}$ See, e.g., SC Res. 1031, supra note 25; SC Res. 954, supra note 25.

${ }^{27}$ See SC Res. 940 (July 31, 1994) (Haiti) (deciding "that the multinational force will terminate its mission ... when a secure and stable environment has been established ... [as determined] by the Security Council, taking into account recommendations from the Member States of the multinational force"). 
Security Council practice has been consistent on this point over a substantial period of time. Resolution 678, by contrast, contains no self-imposed time limit, and none of the resolutions relating to Iraq, including Resolution 1441, explicitly terminated the resolution's endorsement of the use of force. Unless the Security Council had clearly stated, using the same language that it has in the past, that it has terminated Resolution 678's authorization for the use of force, any such authorization continued.

In fact, the view of France, Germany, and Russia directly undermines the idea that UN Security Council enactments are law at all. In 1991, the members of the Security Council unanimously agreed to authorize the use of force against Iraq, and reduced that agreement into the written text of Resolution 678. That text has not been subsequently changed, and the conditions for its authorization continued. If the current members of the Security Council disagreed with Resolution 678, they could have repealed it. To argue that Resolution 678's authorization had somehow dissipated, despite its clear text, simply because some of the current members of the Council no longer agreed with it treats Council resolutions as if they merely recorded temporary diplomatic agreement rather than enacted enduring legal texts. The French, German, and Russian view considers Security Council resolutions to be ad hoc executive edicts, rather than legislative acts-a result that would cause considerable uncertainty about their legal force and when they expire.

Some nations attempted to sidestep the inevitable conclusion to this argument by claiming that Resolution 1441 itself somehow eclipsed Resolution 678's authorization to use force. Resolution 1441, however, twice "[r] ecall[ed]" Resolution 678 and explicitly restated that Resolution 678 referred to the ability of member states "to use all necessary means to uphold and implement resolution 660 (1990) and all subsequent relevant resolutions and to restore international peace and security in the area." ${ }^{28}$ In fact, rather than negate earlier authorizations, Resolution 1441 instead triggered them. Resolution 1441 "[d] ecides" that Iraq "has been and remains in material breach of its obligations under relevant resolutions," in particular the obligations in Resolution 687 regarding Iraq's WMD program. ${ }^{29}$ In addition, the resolution specifies that any false statements or omissions with respect to Iraq's WMD program "shall constitute a further material breach of Iraq's obligations." ${ }^{30}$ The resolution also reminds Iraq that the Security Council has repeatedly warned that "serious consequences" will result from the continued violation of its obligations. ${ }^{31}$ No member of the Security Council found that Iraq had been in compliance with Resolution 1441, Resolution 678 , or Resolution 687.

Resolution 1441's finding that Iraq was in material breach allowed the United States and its allies to terminate the cease-fire created by Resolution 687 and resume the use of force as authorized by Resolution 678 . In the multilateral context, it is well-established that a material breach of a treaty by one of the parties entitles a party "specially affected" by the breach to suspend the operation of the treaty in whole or in part vis-à-vis the defaulting state. ${ }^{32}$ Even if a state party were not "specially affected," however, a material breach that "radically changes" the position of the parties also permits complete or partial suspension. ${ }^{33}$ Resolution 687 explicitly established "a formal cease-fire ... between Iraq and Kuwait, and the [UN] Member States cooperating with Kuwait in accordance with resolution 678 (1990)."34 The state parties to the cease-fire agreement were Iraq, Kuwait, the United States, and the other members

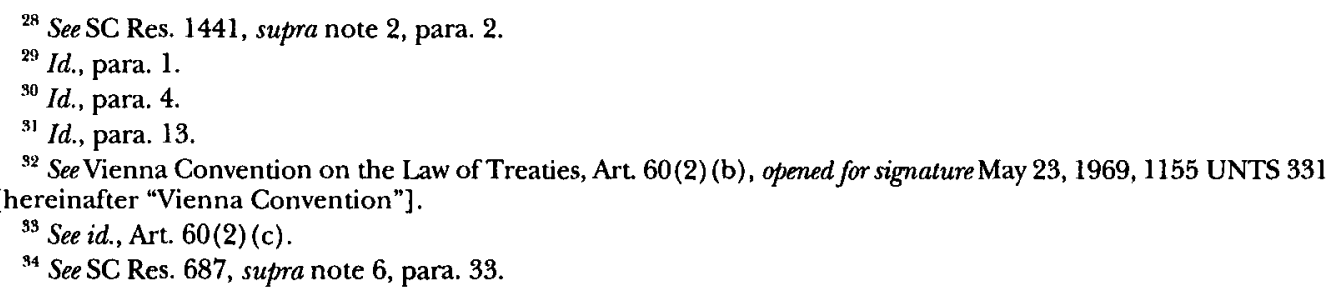


of the coalition in the Gulf war but not the United Nations itself. During the decade after the end of the first Gulf war, Iraq committed numerous material breaches of the cease-fire, in particular by continuing to develop weapons of mass destruction..$^{35}$ Iraq's material breaches of the cease-fire entitled the United States, as a party to the cease-fire, unilaterally to suspend its operation. Under accepted principles of international law, the United States did not need the concurrence of the other parties. ${ }^{36}$ Once the cease-fire was suspended, the United States could rely on Resolution 678 to use force against Iraq to implement Resolution 687 and to restore international peace and security to the area. ${ }^{37}$

The March 2003 attack was also justified under the law governing armistices. Resolution 687 was basically an armistice-unlike a peace treaty, it did not terminate the state of war, but merely "suspend[ed] military operations by mutual agreement between the belligerent parties." 38 A cease-fire allows a party to a conflict to resume hostilities under certain conditions. Under the Hague Regulations, "[a]ny serious violation of the armistice by one of the parties gives the other party the right of denouncing it, and even, in cases of urgency, of recommencing hostilities immediately." ${ }^{39}$ The missile strikes in 1993 and 1998 serve as clear examples of the suspension of a cease-fire and a resumption of hostilities due to serious violations by Iraq ${ }^{40}$ Because the initial use of force in response to the invasion of Kuwait-Operation Desert Storm-was authorized under Resolution 678, subsequent uses of force against Iraq in response to serious violations of the terms of the cease-fire established by Resolution 687 are authorized as

${ }^{95}$ See, e.g., Bush UN Address, supra note 1. Immediately after the cease-fire, Iraq refused to cooperate with UNSCOM and the IAEA. Cn August 15, 1991, after the adoption of SC Res. 687, the Security Council stated that Iraq's "serious violation" of its disarmament obligations "constitutes a material breach of the relevant provisions of [SC Res. 687] which established a cease-fire and provided the conditions essential to the restoration of peace and security in the region." SC Res. 707, supra note 8. Over the next two years, the President of the Security Council issued six different statements reiterating that Iraq's refusal to cooperate with UNSCOM and the IAEA qualified as material breaches of SC Res. 687. See the following: Note by the President of the Security Council, UN Doc. S/25970 (June 18, 1993); UN Doc. S/25091 (Jan. 11, 1993); UN Doc. S/25081 (Jan. 8, 1993); UN Doc. S/24240 (July 6, 1992); UN Doc. S/23663 (Feb. 28, 1992); UN Doc. S/23609 (Feb. 19, 1992).

${ }^{36}$ See Ruth Widgwood, The Enforcement of Security Council Resolution 687: The Threat of Force Against Iraq's Weapons of Mass Destructiom, 92 AJIL 724, 726 (1998) [hereinafter "Wedgwood"]; $c f$. Vienna Convention, Art. 60, supra note 32 (one party may suspend a multilateral treaty with respect to itself).

${ }^{37}$ See Wedgwiod, supra note 36, at 726 (Iraq's breach of the terms of the cease-fire in 1997-1998 "allowed the United States to deem the cease-fire in suspension and to resume military operations to enforce its conditions").

${ }^{38}$ Regulation:s annexed to the Hague Convention on the Law and Customs of War on Land, Oct. 18, 1907, Art. 36, 36 Stat. 2277, 2305 [hereinafter "Hague Regulations"]. See also YORAM DINSTEIN, WAR, AGGRESSION AND SELF-DEFENCE 50 (3d ed. 2001) ("A labelling of Resolution 687 as a 'permanent cease-fire' is a contradiction in terms: a cease-fire, by definition, is a transition-period arrangement.") [hereinafter "Dinstein"].

${ }^{39}$ Hague Regulations, Art. 40, supra note 38; see also U.S. Army Field Manual 1 493, available at <http://www.adtdl. army.mil/cgi-bin/atdl.dll/fm/27-10/Ch7.htm> (hostilities may be resumed only with "convincing proof of intentional and serious violation of [the armistice's] terms by the other party"). The Hague Regulations do not contain any explanation of what might qualify as "urgency," but the U.S. Army's Field Manual sheds some light on the question. According to the Army Field Manual, warning must be given to the other side, unless "the delay incident to formal denunciation and warning seems likely to give the violator a substantial advantage of any kind." Army Field Manual I 493; of. See also 2 L. OPPENHEIM, INTERNATIONAL LAW, A TREATISE: DISPUTES, WAR, AND NEUTRALITY 556 (H. Lauterpacht ed., 7th ed. 1952) ("since the terms 'serious violation' and 'urgency' lack precise definition, the course to be taken is in practice left to the discretion of the injured party") [hereinafter "Oppenheim, Vol. 2"]. In addition to permitting the resumption of hostilities in response to a serious violation of an armistice, the laws of armed conflict permit the United States to resume hostilities at its discretion-provided that warning is given to Iraq. Hague Regulations, Art. 36. If the parties have not made any stipulation regarding notice, it may be provided at any time, and hostilities may recommence immediately after notification. See Army Field Manual I 487; Oppenheim, Vol. 2, supra at 556; see also Howard S. Levie, The Nature and Scope of the Armistice Agreement, 50 AJIL 880, 893 (1956) (although armistices generally do not specify the period of advance notice required, under customary international law, "good faith requires that notice be given of the intention to resume hostilities") (internal quotations and citations omitted).

${ }^{40}$ Dinstein, supra note 38, at 50-51. Whether or not required under international law, warnings were given. See generally UN Doc. S/25091, supra note 35; UN Doc. S/25081, supra note 35; Letter to Congressional Leaders Reporting on Iraq's Compliance With United Nations Security Council Resolutions (Jan 19, 1993), 2 PUB. PAPERSOF GEORGE BusH 2269-70 (1993) [hereinafter "Bush Letter, Jan. 19, 1993"]; President's Radio Address (Dec. 19, 1998), 2 PuB. PAPERS OF Wili.iAM J. CLINTON 2197 (1998) [hereinafter "Clinton Papers (1998)"]. 
well. ${ }^{41}$ Thus, because Iraq refused to fully comply with Resolution 687 , such as by destroying fully its WMD and their delivery systems, it was in "serious violation" of the cease-fire and the United States was justified in resuming the use of force under Resolution 678.

This understanding of the interaction between Resolution 678 and 687 is supported by state practice in the decade following the end of the first Gulf war. The consistent position of the United States had been that Resolution 678's authorization continued. ${ }^{42}$ The United States and Britain, for example, used force against Iraq in 1993 and 1998 in response to Iraq's material breach of Resolution 687. On January 17, 1993, President George H. W. Bush ordered missile strikes against a nuclear facility near Baghdad due to Iraqi infringements of the terms of the cease-fire. Just four days before, President Bush had ordered air attacks on surface-to-missile sites and related facilities in the southern no-fly zone. These attacks, which were joined by Britain and France, appear to have been primarily in response to Iraqi violations of the southern no-fly zone-Iraq had moved surface-to-air missiles into the zone to threaten coalition aircraft-but President Bush also pointed to Iraq's " "failure to live up to the resolutions." "43 The president's report to Congress on the attack takes note of a statement by the UN secretary-general explaining that "'the forces that carried out the [January 13th] raid have received a mandate from the Security Council, according to Resolution 687 , and the cause of the raid was the violation by Iraq of Resolution 687 concerning the cease-fire . . . [T] his action . . . conformed to the Charter of the United Nations." 44

In December 1998, the United States launched seventy hours of missile and aircraft strikes against Iraq "in response to Iraqi breaches of its obligations under resolutions of the United Nations Security Council." ${ }^{45}$ President Clinton explained that the military action, which targeted facilities actively involved in Iraq's WMD programs or that threatened Iraq's neighbors or U.S. forces, was

consistent with and has been taken in support of numerous U.N. Security Council resolutions, including Resolutions 678 and 687, which authorize U.N. Member States to use "all necessary means" to implement the Security Council resolutions and to restore peace and security in the region and establish the terms of the cease-fire mandated by the Council, including those related to the destruction of Iraq's WMD programs. ${ }^{46}$

\footnotetext{
${ }^{41}$ As noted, the Hague Regulations provide either that Iraq must be warned or that such a warning may be avoided because it would be likely to give Saddam Hussein a substantial advantage. There is a good argument that Iraq was warned of a resumption of hostilities by SC Res. 1441. SC Res. 1441 cautions that Iraq's continued violation of its international obligations will result in "serious consequences." See SC Res. 1441, supra note 2, para. 13. Twice before, military force against Iraq has followed warnings by the Security Council that Iraq's continued intransigence would result in serious consequences. On January 8 and 11, 1993, the president of the Security.Council warned Iraq that "serious consequences" would follow if it failed to comply with its international obligations. See UN Doc. S/25091, supra note 35; UN Doc. S/25081, supra note 35.

${ }^{42}$ See, e.g., Letter to Congressional Leaders Reporting on Iraq's Compliance With United Nations Security Council Resolutions (Sept. 16, 1991), 2 PUB. PAPERS OF GEORGE BUSH 1 164-65 (1991) (explaining-after the adoption of SC Res. 687-that the United States was willing to take military action to implement SC Res. 678's call for the restoration of international peace and security to the region); Legal Authority for the Possible Use of Force Against Iraq, 92 ASIL PROC. 136, 142 (1998) ("In the U.S. Government's view, there is a continuing right to use force [to respond] to such [material] breaches regardless of whether there is further [Security Council] authorization to respond.") (Michael Matheson, Principal Deputy Legal Adviser, Department of State). SC Res. 687 itself explicitly reaffirmed SC Res. 678, as did UN Security Council Resolutions 686 and 949. See SC Res. 949 (Oct. 15, 1994); SC Res. 686 (Mar. 2, 1991).

${ }^{43}$ Barton Gellman \& Ann Devroy, Military Action Against Iraq Signaled by Administration, WASH. Post, Jan. 14, 1993, at A1 (quoting President Bush); see also Statement by Marlin Fitzwater, United States Mission to the United Nations Press Release USUN-1 (93) (Jan. 13, 1993) (“[T]he Government of Iraq should understand that continued defiance of U.N. Security Council resolutions and related coalition demarches will not be tolerated.") .

${ }^{44}$ See Bush Letter, Jan. 19, 1993, supra note 40.

${ }^{45}$ See Letter to Congressional Leaders on the Military Strikes Against Iraq (Dec. 18, 1998), in Clinton Papers (1998), supra note 40 , at 2195 .

${ }^{46} I d$. at $2195-96$.
} 
As the U.S. arnbassador to the United Nations explained to the Security Council, Iraq had acted in "flagrant material breach of resolution 687" by interfering with UNSCOM's inspections, and coalition forces responded under the authority provided by UN resolutions. ${ }^{47}$

In sum, well-established principles of UN Security Council practice, treaty law, and armistice law allowed the United States to suspend the cease-fire in response to Iraq's material breaches of Resolution 687 . The United States then could rely on Resolution 678 to use "all necessary means" to bring Iraq into compliance. Nothing in Resolution 1441 suggested that the Security Council needed to adopt any additional resolution to establish the existence of further material breaches to provide the basis for the use of force under Resolution 678 . Indeed, Resolution 1441 left intact Resolution 678's reference to the use of force. Resolution 1441 neither revoked Resolution 678's language concerning the use of "all necessary means" against Iraq, nor terminated its effect in any way.

\section{USE OF FORCE AGAINST IRAQ IN ANTICIPATORY SELF-DEFENSE}

Independent of the support provided by UN Security Council resolutions, authority for the armed intervention in Iraq stemmed from the national right of self-defense. Article 51 of the UN Charter recognizes and affirms, but does not limit, that "inherent" right under international law:

Nothing in the present Charter shall impair the inherent right of individual or collective self-deferise if an armed attack occurs against a Member of the United Nations, until the Security Council has taken measures necessary to maintain international peace and security. ${ }^{48}$

Despite the long-standing recognition of a nation's right to self-defense, some argue that Article 51 has limited the right to permit only a response to an actual "armed attack." Some even argue that an armed attack must occur across national borders to trigger Article $51 .{ }^{49}$ Under this interpretation, the UN Charter superseded the existing right under customary international. law to take reasonable anticipatory action in self-defense. There is no indication that the drafters of the UN Charter intended to limit the customary law in this way, nor that the United States so understood the Charter when it ratified. Instead, Article 51 merely partially expressed a right that exists independent of the UN Charter. ${ }^{50}$

The customary international law right to use force in anticipatory self-defense is a wellestablished aspect of the "inherent right" of self-defense. Leading up to the Cuban missile crisis, the Office of Legal Counsel of the Department of Justice explained in an internal memorandum:

\footnotetext{
${ }^{47}$ See UN Security Council Press Release, Security Council Meets to Discuss Military Strikes Against Iraq; Some Members Challenge Use of Force Without Council Consent (Dec. 16, 1998), UN Doc. SC/6611, at 1-2, 7. International support for the 1998 airstrikes was reflected by the offers of Argentina, Australia, Canada, the Czech Republic, Denmark, Germany, Hungary, the Netherlands, New Zealand, Portugal, Spain, and the United Kingdom to contribute facilities, equipment or forces to the U.S. military effort, and of Kuwait for the use of its air facilities. Although Britain and Japan spoke in favor of the strikes, the Russian Federation labeled them as "violat[ing] the principles of international law and the principle of the [UN] Charter." Id. at 4. Of the Security Council members at the time, China, Costa Rica, Sweden, Brazil, Gambia, Kenya, and Gabon also spoke against the 1998 strikes-some preferring the peaceful settlement of disputes and some criticizing the unilateral use of force. Id. at 5-10.

${ }^{48}$ UN CHARTER Art. 51.

${ }^{49}$ See, e.g., IAN BROWNLIE, INTERNATIONAL LAW AND THE USE OF FORCE BY STATES 275-80 (1963); LOUIS HENKIN, HOW NATIONS BEHAVE: LAW AND FOREIGN POLICY 141 (2d ed. 1979).

${ }^{50}$ See Myres S. McDougal, The Soviet-Cuban Quarantine and Self-Defense, 57 AJIL 597, 599 (1963) ("There is not the slightest evidence that the framers of the United Nations Charter, by inserting one provision which expressly reserves a right of self-defense, had the intent of imposing by this provision new limitations upon the traditional right of states."); Oscar Schachter, The Right of States to Use Armed Force, 82 MiCH. L. REV. 1620, 1634-35 (1984); Abraham D. Sofaer, International Law and Kosovo, 36 STAN.J. INT'L L. 1, 16 (2000); THOMAS M. FRANCK, RECOURSE TO FORCE: STATE ACTION AGAINST THREATS AND ARMED ATTACKS 97-99 (2002); see generally CHRISTINE GRAY, INTERNATIONAL LAW AND THE USE OF FORCE 84-119 (2000).
} 
The concept of self-defense in international law of course justifies more than activity designed merely to resist an armed attack which is already in progress. Under international law every state has, in the words of [then-Secretary of State] Elihu Root, "the right ... to protect itself by preventing a condition of affairs in which it will be too late to protect itself." 51

The classic formulation of the right of anticipatory self-defense arose from the Caroline incident. In 1837, the steamer Caroline had been supplying armed insurgents against British rule in Canada with reinforcements of men and materials from the United States. In response, a British force from Canada entered U.S. territory at night, seized the Caroline, set the ship on fire, and launched it down Niagara Falls, killing two U.S. citizens in the process. The British claimed that they were acting in self-defense, and Secretary of State Daniel Webster called upon the British to show that the

necessity of self-defence [was] instant, overwhelming, leaving no choice of means, and no moment for deliberation ... [and that the British force], even supposing the necessity of the moment authorized them to enter the territories of the United States at all, did nothing unreasonable or excessive; since the act, justified by the necessity of self-defence, must be limited by that necessity, and kept clearly within it. ${ }^{52}$

The next year, Lord Ashburton, who had been sent by the British as a special minister to resolve the Caroline dispute and other related matters, implicitly accepted this test byjustifying Britain's actions in these terms. ${ }^{53}$ Webster's formulation was reaffirmed a century later by the International Military Tribunal at Nuremberg, when it ruled that the German invasion of Norway in 1940 was not defensive because it was unnecessary to prevent an "imminent" Allied invasion. ${ }^{54}$

The Caroline test has been distilled into two principal requirements. First, the use of force must be necessary because the threat is imminent and, thus, pursuing peaceful alternatives is not an option. Second, the response must be proportionate to the threat ${ }^{55}$ International law does not supply a precise or detailed definition of what it means for a threat to be sufficiently "imminent" to justify the use of force in self-defense as necessary. Although the dictionary definition of "imminent" focuses on the temporal, ${ }^{56}$ under international law the concept of imminence must encompass an analysis that goes beyond the temporal proximity of a threat to include the probability that the threat will occur. ${ }^{57}$

In addition to the probability of the threat, the threatened magnitude of harm must be relevant. The advent of nuclear and other sophisticated weapons has dramatically increased the degree of potential harm, and the importance of the temporal factor has diminished. Weapons of mass destruction threaten devastating and indiscriminate long-term damage to large segments of the civilian population and environment. ${ }^{58}$ In addition, the danger posed by WMD is exacerbated by the possibility that the means of delivery may be relatively unsophisticated-

\footnotetext{
${ }^{51}$ Memorandum for the Attorney General, from Norbert A. Schlei, Assistant Attorney General, Office of Legal Counsel, Re: Legality under International Law of Remedial Action Against Use of Cuba as a Missile Base by the Soviet Union (Aug. 30, 1962), at 2, reprinted in 6 Green Bag 2d 195, 196 (2003).

${ }^{52}$ See Letter from Daniel Webster, U.S. Secretary of State, to Henry Fox, British Minister in Washington (Apr. 24, 1841), in 29 BRITISH AND FOREIGN STATE PAPERS 1840-1841, at 1138 (1857).

${ }^{53}$ See Letter from Lord Ashburton to Daniel Webster, U.S. Secretary of State (July 28, 1842), in 30 BRITISH AND FOREIGNSTATE PAPERS 1841-1842, at (1858), also available at $<$ http://www.yale.edu/lawweb/avalon/diplomacy/ britain/br-1842d.htm>.

${ }^{54}$ See International Military Tribunal (Nuremberg)-Judgment and Sentences, 41 AJIL 172, 205 (1947) ("preventive action in foreign territory is justified only in case of 'an instant and overwhelming necessity for self-defense, leaving no choice of means, and no moment for deliberation'") (quoting the Caroline case); see alsoD. W. BOWETT, SELF-DEFENCE IN INTERNATIONAL LAW 142-43 (1958).

${ }^{55}$ See Dinstein, supra note 38, at 208-12, 219-20; see also McDougal, supra note 50, at 597-98.

${ }^{56}$ See WEBSTER's THIRD NEW INTERNATIONAL DiCTIONARY (unabridged) 1130 (1993).

${ }^{57}$ See Case Concerning the Gabčíkovo-Nagymaros Project (Hungary/Slovakia), 1997 ICJ REP. 7 (Sept. 25).

${ }^{58}$ See Legality of the Threat or Use of Nuclear Weapons (Advisory Opinion), 1996 ICJ REP. 95, at I 36 (July 8).
} 
for example, a "dirty bomb" driven into a building by a suicide bomber, or the spread of a biological agent with an ordinary crop duster. At the same time, the development of advanced missile technology has vastly improved the capability for stealth, rendering threats more imminent because there is less time to prevent their launch.

State practice since the development of nuclear weapons and sophisticated delivery systems demonstrates the evolution of the concept of imminence. During the Cuban missile crisis, for example, the United States labeled the secret establishment of long-range nuclear missile bases in Cuba by the Soviet Union as an "immediate" threat to U.S. security and imposed a quarantine on offensive military equipment to Cuba in self-defense. ${ }^{59}$ Although the sudden and secret preparation of the missile bases undoubtedly "add[ed] to an already clear and present danger," their positioning in Cuba constituted a less immediate temporal threat of armed attack on the United States than that contemplated by previous applications of the Caroline test. There was no indication that the Soviet Union would use them either immediately, or even in the near term. ${ }^{60}$

In the past two decades, the United States has used military force in anticipatory self-defense against Libya., Panama, Iraq, Afghanistan, and the Sudan. The United States justified the 1986 strikes against Libya in large part as necessary to forestall future terrorist attacks. ${ }^{61}$ Although several countries criticized the U.S. strikes by supporting a UN resolution condemning the attack as a violation of the UN Charter, Australia, Denmark, France, and the United Kingdom joined the United States in opposing the resolution. ${ }^{62}$ The United States again responded in self-defense to an imminent threat to U.S. lives when it took military action in Panama on December $20,1989 .{ }^{63}$ In the midst of the fighting, the Security Council considered a draft resolution that would have labeled the invasion as "a flagrant violation of international law," but Great Britain, France, and Canada joined the United States in opposing the resolution. ${ }^{64}$ In 1998 the United States launched cruise missile attacks in self-defense against terrorist training camps and installations in Afghanistan used by Osama bin Laden's organization and against a facility in Sudan being used to produce materials for chemical weapons. ${ }^{65}$ The Security Council took no formal action in response.

Self-defense has served specifically as a justification for strikes against Iraq in the decade preceding the March 2003 conflict. In June 1993, for example, the United States justified its strike on Iraqi intelligence headquarters as self-defense because of "compelling evidence" that Iraq had attempted to assassinate President George H. W. Bush. As President Clinton explained:

\footnotetext{
${ }^{59}$ See Proclamation 3504: Interdiction of the Delivery of Offensive Weapons to Cuba (Oct. 23, 1962), PUB. PAPERS OF JOHN F. KEN.NEDY 809, 810 (1962); White House Statement on Soviet Proposals Relating to International Security (Oct. 27, 1962), id., at 813.

${ }^{60}$ See Radio and Television Report to the American People on the Soviet Arms Buildup in Cuba (Oct. 21, 1962), $i d$. at 806-07. It should be noted that while the Department of Justice may have believed the quarantine to be a lawful exercise of self-defense, the official justification offered diplomatically relied upon authorization by the Organization of American States.

${ }^{61}$ See Letter to the Speaker of the House of Representatives and the President Pro Tempore of the Senate on the United States Air Strike Against Libya (Apr. 16, 1986), 1 PUb. PAPERS OF RonAld REAGaN 478 (1986).

${ }^{62}$ See UN Doc. S/PV. 2682 (Apr. 21, 1986).

${ }^{63}$ See Letter to the Speaker of the House of Representatives and the President Pro Tempore of the Senate on the United States Military Action in Panama (Dec. 21, 1989), 2 PUB. PAPERS OF GeORGE BUSH 1734 (1989) ("The deployment of U.S. Forces is an exercise of the right of self-defense recognized in Article 51 of the United Nations Charter and was necessary to protect American lives in imminent danger ....").

${ }^{64}$ UN Doc. \$/21048 (Dec. 22, 1989); UN Doc. S/PV. 2902 (Dec. 23, 1989).

${ }^{65}$ See Letter to Congressional Leaders Reporting on Military Action Against Terrorist Sites in Afghanistan and Sudan (Aug. 21, 1998), in Clinton Papers, supra note 40, at 1464 (1998) ("These strikes were a necessary and proportionate response to the imminent threat of further terrorist attacks against U.S. personnel and facilities. These strikes were intended to prevent and deter additional attacks by a clearly identified terrorist threat.").
} 
The evidence of the Government of Iraq's violence and terrorism demonstrates that Iraq poses a continuing threat to United States nationals and shows utter disregard for the will of the international community as expressed in Security Council Resolutions and the United Nations Charter. Based on the Government of Iraq's pattern of disregard for international law, I concluded that there was no reasonable prospect that new diplomatic initiatives or economic measures could influence the current Government of Iraq to cease planning future attacks against the United States. ${ }^{66}$

The objective of the strikes was to diminish Iraq's capability to support violence against the United States and others, and "to deter Saddam Hussein from supporting such outlaw behavior in the future. ${ }^{\prime 77}$ The Security Council rejected the plea of the Iraqi ambassador to condemn the U.S. action as an act of aggression.

The new threat of nuclear weapons apparently is not, however, sufficient to erase completely any requirement of temporality. For example, the international community did not consider the threat posed by an Iraqi nuclear reactor before it had become operational to be sufficient to justify its destruction by Israel in $1981 .^{68}$ Nonetheless, the nature of the Iraqi threat has changed significantly in the past twenty years. In 1981, Iraq was permitted to have nuclear materials under the safeguards of the IAEA, and Saddam Hussein had not yet used chemical weapons against Iran and his own people, invaded Kuwait, or spent over a decade flouting his country's international obligations to destroy and cease to develop WMD and their means of delivery. In other words, the imminence of a likely attack by Iraq has increased since 1981 because Iraq has demonstrated a WMD capability and a willingness to use it.

The use of force in anticipatory self-defense must be necessary and proportional to the threat. At least in the realm of WMD, rogue nations, and international terrorism, however, the test for determining whether a threat is sufficiently "imminent" to render the use of force necessary at a particular point has become more nuanced than Secretary Webster's nineteenth-century formulation. Factors to be considered should now include the probability of an attack; the likelihood that this probability will increase, and therefore the need to take advantage of a limited window of opportunity; whether diplomatic alternatives are practical; and the magnitude of the harm that could result from the threat. If a state instead were obligated to wait until the threat were truly imminent in the temporal sense envisioned by Secretary Webster, there is a substantial danger of missing a limited window of opportunity to prevent widespread harm to civilians. Finally, in an age of technologically advanced delivery systems and WMD, international law cannot require that we ignore the potential harm represented by the threat.

Applying the reformulated test for using force in anticipatory self-defense to the potential use of force against Iraq reveals that the threat of a WMD attack by Iraq, either directly or through Iraq's support for terrorism, was sufficiently "imminent" to render the use of force necessary to protect the United States, its citizens, and its allies. The force used was proportionate to the threat posed by Iraq; in other words, it was limited to that which is needed to eliminate the threat, including the destruction of Iraq's WMD capability and removing the source of Iraq's hostile intentions and actions, Saddam Hussein.

\footnotetext{
${ }^{66}$ See Letter to Congressional Leaders on the Strike on Iraqi Headquarters (June 28, 1993), 1 PUB. PAPERS OF William J. Clinton 940 (1993).

${ }^{67}$ See Address to the Nation on the Strike on Iraqi Intelligence (June 26, 1993), id. at 938 (1993). Similarly, the January 17, 1993, strike on a nuclear facility in Baghdad, while primarily designed to encourage Iraq to comply with its obligations under UN Security Council resolutions, was undertaken in part to prevent the facility from being used again to support Iraq's nuclear weapons program. See Bush Letter, Jan. 19, 1993, supra note 40, at $2269-70$.

${ }^{68}$ See SC Res. 487 (June 19, 1981) (unanimously "condemn[ing]" the Israeli strikes as a "clear violation of the Charter of the United Nations and the norms of international conduct.").
} 


\section{CONCLUSION}

International law permitted the use of force against Iraq on two independent grounds. First, the Security Council authorized military action against Iraq to implement the terms of the cease-fire that suspended the hostilities of the 1991 Gulf war. Due to Iraq's material breaches of the cease-fire, established principles of international law-both treaty and armistice lawpermitted the United States to suspend its terms and to use force to compel Iraqi compliance. Such a use of force was consistent with U.S. practice both with regard to Iraq and with regard to treaties and cease-fires. Second, international law permitted the use of force against Iraq in anticipatory self-defense because of the threat posed by an Iraq armed with WMD and in potential cooperation with international terrorist organizations.

This approach to the use of force against Iraq has significant implications for the future. To be sure, Iraq could be seen as a unique case. Due to the web of Security Council resolutions going back more than a decade, the United States and its allies could draw sufficient legal authority from those enactments alone. No other use of force in the near future may receive such support from the Security Council. On the other hand, Iraq could be said, unfortunately, to represent the coming challenges to international peace and stability as a rogue state that has WMD and supports terrorism. In this type of security environment, the United States and its allies may well have to rely exclusively upon their right to anticipatory self-defense in order to use force against such nations. In order to address the challenge posed by this new threat, the international legal system will have to adapt to take into account the probability of an attack, the magnitude of the possible harm, and the windows of opportunity within which proportionate force may be used.

The use of: force in anticipatory self-defense against terrorist groups armed with WMD, or against the rogue nations that support them, will depend on three factors that go beyond mere temporal imminence. First, does a nation have WMD and the inclination to use them? In the case of Iraq, the record made clear that Saddam Hussein both possessed WMD and had used them against external enemies (Iran) and his own citizens. In future cases, the possession of WML and signs of hostile intent must be taken into account in deciding whether to use force preemptively. That decision will rely, in part, on intelligence about rogue nations' WMD programs, their ability to acquire components and technical knowledge, and their ability to assemble a weapon.

Second, nations will have to use force while taking into account the available window of opportunity. If a state waits until a terrorist attack is on the verge of being launched, it likely will be unable to protect the civilians who are being targeted, especially against suicide bombers who seem immune to traditional methods of deterrence. Terrorists are also difficult to locate and track and seek to escape detection by concealing themselves and their activities among an innocent civilian population. As terrorists burrow more deeply into this population, defensive options may become more limited. Due to these considerations, a state may need to act when it has a window of opportunity to prevent a terrorist attack and simultaneously minimize civilian casualties. Preventing a terrorist attack using WMD may require that the United States and its allies take advantage of a window of opportunity that opens before a rogue nation transfers WMD to a terrorist organization. Were the United States, for example, to wait until a rogue nation has transferred WMD to terrorist groups, it could become extremely difficult to determine where and when WMD would be used given the sporadic nature of terrorist attacks and the terrorist tactic of infiltrating the civilian population.

Third, nations will have to take into account that the degree of harm from a WMD attack would be catastrophic. The combination of the vast potential destructive capacity of WMD and the modest means required for their delivery make them more of a threat than the military forces of many countries. Chemical weapons and biological agents are easy to hide, and small quantities can have a devastating effect on the civilian population. This threat only multiplies 